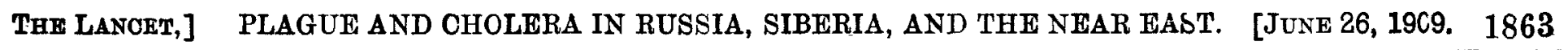

seem" not possessed of " knowledge of the subject on which they are asked to adjudicate."

I am, yours faithfully,

Southport. June 19th, $1909 . \quad$ A. A. BRADBURNE.

\section{TROPICAL ADENITIS AND PLAGUE.} To the Editor of THE LANCET.

SIR, - With reference to your annotation in THE LANCET of June 12th the following note bearing on the subject, which was personally investigated, may be of interest.

In January, 1906, owing to a couple of cases of bubonic plague having occurred amongst the Lascars of a transport which had conveyed a European regiment from the West Indies to Calcutta, the entire regiment was segregated on the maidan outside Fort William, and the men submitted to a thorough medical examination. Several suspicious cases of adenitis with slight pyrexia and malaise were detected and placed in an isolation hospital. These cases were added to daily for about a week, and although the specific bacilli could not be recovered, there was no doubt at the time that there was some relationship between the plague-infected ship and the cases of adenitis, which were diagnosed and treated as pestis minor. With a small dose of not very malignant plague bacilli the European develops adenitis or pestis minor, a not uncommon affection amongst laboratory workers in the tropical areas where plague is met with.

I am, Sir, yours faithfully,

E. B. Knox, M.D. Dub., Captain, R.A.M.C.

Putney, S.W., June 19th, 1909.

\section{HAMPSTEAD GENERAL HOSPITAL: THE} MALCOLM MEMORIAL.

\section{To the Editor of THE LANCET.}

SIR,-At a meeting of the council held on Feb. 23rd last, it was decided to raise a fund amongst the friends and admirers of the late Mr. William Forrest Malcolm for the purpose of providing a suitable tribute to his memory. He was one of the founders of the institution and occupied the position of treasurer from its commencement to the end of his life, extending over a period of 28 years, and by his continuous work and munificent support was largely instrumental in placing the institution in its present state of efficiency and usefulness. With the approval of Mr. Malcolm's family, it has been decided that the memorial shall take the form of a portrait, to be painted by Mr. Hillyard Swinstead and placed in the board-room of the hospital.

The council has decided that subscriptions shall be limited to the sum of one guinea each, so that all may have an opportunity of showing their appreciation of Mr. Malcolm, whose loss is so deeply felt by all who knew him, and whose generosity and goodness must be admired by many who may not have been personally acquainted with him. To defray the cost of the painting the sum of 100 guineas will be required. Will those desiring to contribute, kindly send their subscription to the secretary at the hospital at their early convenience.

We remain, yours faithfully,

EDMD. K. BLYTH,

ERNEST ColluINs, Special Committee, Chas. Johnston, \}Malcolm Memorial.

June 11tb, 1909. R. A. OWTHWAITE.

Jand

SALFORD Guardians AND FeEble-Minded GIRLS AND WoMEN. - The Salford Guardians are about to make a good move as regards the care of the feeble-minded girls and women who are now in their care or who may be so in the future. One of the lady members recently moved that a committee be appointed to consider the advisability of providing a home for them apart from the workhouse. The guardians have on their hands some buildings not in use which could be put in order and these poor creatures accommodated and an attempt made to draw out what mental powers they possess. It would, of course, be necessary to have a teacher trained in the care of the feebleminded, but the mover of the resolution did not think the cost would be great. The disadvantage of the scheme, as compared with that carried out at Sandal Bridge, is, of course, that the inmates will be able to leave when they like, but the hope is that they may be induced to stay in a home where they could be tanght housekeeping, laundry work, cooking, and so on. The motion was carried unanimously.

\section{PLAGUE AND CHOLERA IN RUSSIA, SIBERIA, AND THE NEAR EAST.}

(From the British Delegate to the Constantinople BOARD OF HEATTH.)

Plague in Jeddah.

THE outbreak of plague in Jeddah has come to an end with the approach of the hot season. The statistics of the epidemic were brought down to the week ending April 11th in $\mathrm{my}$ last letter on the subject. ${ }^{1}$ In the week ending April 18th only one case and one death occurred, and in that ending April 25th there were reported one fresh case and two deaths. The present revival of the disease lasted from Dec. 12th, 1908, to April 21st, 1909; in that period 178 cases, with 160 deaths, have been recorded. Of the 178 cases only 28 were seen during life, the remaining 150 came to the knowledge of the authorities only after death. Only ten of the cases were removed to hospital; of these six are said to have recovered, thanks to the treatment by serum; six other cases in the town were submitted to the same treatment, and of these four recovered. It is noted that the large majority of cases were bubonic in character; only four pneumonic cases were seen (two in life and two after death). In the bubonic cases the buboes were most often situated in the groin.

Yanbo appears to have escaped infection on this occasion. It is interesting, however, to note that an imported case of plague occurred at the lazaret of $\mathrm{El}$ Tor, in a member of the crew of a ship coming from Yanbo. This ship, the s.s. Mariout, arrived at Tor on March 1st; the patient was a stoker; he was the only case of plague seen this season in the Tor lazaret. The ship had been in Jeddah a full month and a half previously; had taken a batch of Egyptian pilgrims (among whom no cases of plague were observed) to Tor, where the ship had been disinfected and had its rats destroyed by a Clayton apparatus; had then proceeded to Yanbo, but finding no pilgrims there returned to Tor, where, as just stated, the case of plague occurred. It would seem that the ship had in all probability become infected when at Jeddah and that the infection had remained latent during a month and half. If so, the incident is in every way analogous with the occurrence of cases of plague in the Thames in the autumn of 1896 on board a ship from Indian ports ; and both incidents tend to show that mere quarantine, unless it be prolonged over an impossibly long period, can never suffice to prevent the importation of plague from one country to another.

\section{Plague in Bagdad.}

It will be recalled that the outbreak of plague in Bagdad appeared to have come to an end in February, and that the town was declared "clean" on Feb. 23rd. But on May 5th two fresh cases were discovered; of these one occurred in the Abu Sefein quarter of the town, and the other in the Sedria quarter. In both districts (which are situated near the northern end of the town) plague was prevalent during the outbreak of last year. On May 12th three fresh cases were reported, and on the $23 \mathrm{rd}$ one. Since that date no further cases have been seen, and the measures which had been once more put in force upon departures from Bagdad by river and road were again suppressed on June 8th.

Plague in Bahrein and the Persian Gulf.

Outbreaks of plague have occurred more than once in recent years in the Bahrein Islands. This group of islands is situated on the south-western shores of the Persian Gulf and is under British protection. The reappearance of the disease there was reported on May 12th, when 3 cases and 2 deaths haa occurred. Down to May 15th there had been 6 cases with 4 deaths. In the week ending May 22nd as many as 18 deaths from plague were recorded, but in that ending May 28th (sio) the number of deaths fell to 3 . The health of the other Gulf ports has remained good. The only measures imposed in Turkish ports against Bahrein have been a medical visit, disinfection, and application of the circular concerning rat destruction.

Some other imported cases of plague have recently occurred in other ports of the Persian Gulf. On April 14th a case was landed at Muscat from the ss. Africa and died on the 16th. 